\title{
Microbiological evaluation of isolated compounds from the bark of Maytenus guianensis Klotzsch ex Reissek (Celastraceae)
}

\author{
Avaliação microbiológica dos isolados das cascas de Maytenus guianensis Klotzsch ex \\ Reissek (Celastraceae)
}

\author{
Renato Abreu Lima ${ }^{1,2^{*}}$; Fernanda Bay-Hurtado²; Dionatas Ulises de Oliveira Meneguetti ${ }^{3}$; \\ João Bezerra Facundo2; Júlio Sancho Linhares Teixeira Militão²; Najla Benevides Matos;; \\ Valdir Alves Facundo ${ }^{2}$
}

${ }^{1}$ Postgraduate Program of Biodiversity and Biotechnology of the Legal Amazon (Bionorte Network), Manaus, Amazonas State, Brazil;

2Department of Chemistry of the Federal University of Rondônia (UNIR), Porto Velho, Rondônia State, Brazil; ${ }^{3}$ College of Application (CAP) of the Federal University of Acre (UFAC), Rio Branco, Acre, Brazil; ${ }^{4}$ Research Center for Tropical Medicine, (CEPEM), Porto Velho, Rondônia, Brazil. * E-mail: renatoabreu07@hotmail.com

\begin{abstract}
Maytenus guianensis Klotzsch ex Reissek is a brazilian Amazon plant widely used in tradicional medicine to treat malaria, leishmaniasis and cancer. Due to the increasing number of resistant strains of microorganisms to known antimicrobial substances, various extracts of medicinal plants are being assayed with the purpose of developing new compounds with antimicrobial activities. Thus, the present work aimed to evaluate the biological potential of isolated substances of the bark of M. guianensis on bacteria. The barks were collected at the Reserva Florestal Adolpho Ducke, in Manaus-AM. After, they were dried and grinded, being subjected to Soxhlet extraction with different solvants according to their polarity degree. The isolated substances were diluted with DMSO $2 \%$, and for the evaluation of the antibacterial potential, the agar well diffusion technique was used. The design was totally randomized with two replicas per treatment. The evaluation consisted on measuring bacteria colonial growth after 24 hours of the beginning of the experiment. The results obtained from the isolated substances of M. guianensis presented inhibitory effect against at least four out of the five bacteria tested, where satisfactory inhibition halos were noted. The results highlight the antimicrobial potential of this plant, which may be promising for the development of new drugs.

Keywords: Celastraceae. Maytenus guianensis. Bacteria. Biological assays.
\end{abstract}

\section{Resumo}

Maytenus guianensis Klotzsch ex Reissek é uma planta da Amazônia brasileira muito utilizada na medicina popular contra malária, leishmaniose e câncer. Com o aumento dos microrganismos resistentes às substâncias antimicrobianas já conhecidas, vários extratos de plantas medicinais estão sendo testados com a finalidade de procurar novos compostos com atividade antimicrobiana reconhecida. Assim, este trabalho visa avaliar o potencial biológico das substâncias isoladas das cascas de M. guianensis sobre bactérias. As cascas foram coletadas na Reserva Florestal Adolpho Ducke em Manaus-AM. Posteriormente, foram devidamente secas e trituradas, sendo submetidas à extração em aparelho de Soxhlet com diferentes solventes de acordo com grau de polaridade. As substâncias isoladas foram diluídas com DMSO a $2 \%$ e para avaliar o potencial biológico sobre as bactérias, utilizou-se à técnica de difusão em ágar em poços. O delineamento foi o inteiramente casualizado com duas repetições por tratamento. A avaliação teste consistiu em medir o crescimento das colônias das bactérias, após 24 horas do início do experimento. Os resultados obtidos das substâncias isoladas de M. guianensis apresentaram efeito inibitório contra pelo menos quatro das cinco bactérias testadas notando-se halos de inibição satisfatórios. Os resultados sinalizam o potencial antimicrobiano dessa planta, podendo ser promissoras para estudos de desenvolvimento de novos fármacos.

Palavras-chave: Celastraceae. Mayenus guianensis. Bactérias. Ensaios Biológicos. 
Lima et al.: + Microbiological evaluation of Maytenus guianensis

\section{Introduction}

Brazil has the greatest plant diversity of the world, with an estimated number of over $20 \%$ of the total species of the planet. With more than fifty thousand species described, corresponding to $22 \%$ of the total, this rich biodiversity is accompanied by a wide acceptance of medicinal plant use and traditional knowledge associated to. Approximately $48 \%$ of the medicines utilized in therapeutics are originated directly or indirectly from natural products, especially medicinal plants (CARVALHO et al., 2007).

In Amazon, there are several plant species bearing medicinal properties (OSAKADA, 2009), including the species belonging to the Celastraceae family, composed by 98 genera and roughly 1264 species (FONSECA ET AL., 2007; LORENZI \& MATOS, 2008; OLIVEIRA et al., 2012), distributed all over the world, particularly in the tropical and subtropical regions, including the north of Africa, South America and Asia (SPIVEY et al., 2002; DUARTE et al., 2010; HURTADO, 2013; MOHAMED \& PERWEZ, 2014).

Furthermore, the family has species with great therapeutical relevance, presenting various pharmacological activities, such as: antiulcerogenic, insecticidal, immunosuppressive, anti-rheumatic, antibacterial and anticancer (FONSECA et al., 2007), and given that, species of this family have been object of many phytochemical investigations and secondary metabolites isolated of these species have shown great biological activity (FONSECA et al., 2007; ALMEIDA et al., 2010; DING et al., 2010; LIMA et al., 2010; ANTONISAMY et al., 2011; KENNEDY et al., 2011; SANTOS et al., 2013), of which we can cite the friedelane pentacyclic triterpenes, quinonamethides, sesquiterpenes, secofriedelanes, steroids, agarofuranic derivatives, proanthocyanidin glycosides, flavonoids, sesquiterpene pyridine alkaloids and catequines (SILVA et al., 2008; SOUSA et al., 2012; HURTADO, 2013).

Maytenus guianensis is a small tree, endemic of terra-firme regions in Amazon, and is popularly known as chichuá, xixuá, chuchahuasi, chucchu huashu, chuchuasi, chuchasha and tonipulmon (DUKE \& VÁSQUEZ, 1994; REVILLA, 2002).

Its roots and stems are used as analgesic, anti-inflammatory, aphrodisiac, muscular relaxant, antirrheumatic and anti-diarreaic. The species is also indicated for the treatment of arthritis, impotence, cold, bronchitis, haemorrhoid, helminthiases, lumbago, external ulcerae and ginecological uses (BORRÁS, 2003). As a cosmetic, it is used in cutaneous eruptions and prevents skin cancer (REVILLA, 2002), besides of its antiparasitic action (MACARI et al., 2006), demonstrating a great ethnopharmacological potential to be explored.

Bacteria easily develop resistance to some antibacterial agents. However, since the discovery of first antimicrobials, a wide variety of agents have been studied for its activities on bacterial growth or survival (HURTADO, 2013).

Considering the diversity of substances on plants and the possibility to find new antibacterial substances, this work aimed to evaluate the activity of substances isolated from the barks of $M$. guianensis against Staphylococcus aureus (ATCC 29213), methicillin-resistant Staphylococcus aureus (MRSA) (ATCC 25923), Klebisiela pneumoniae (ATCC 13883), Pseudomonas aeroginosa (ATCC 27853) and Escherichia coli (ATCC 25922).

\section{Methods}

The phytochemical study of the barks of $M$. guianensis was carried out at the Research Laboratory of Chemistry of Natural Products of the Federal University of Rondônia (UNIR), on Porto Velho-RO. The collection of the fresh barks of M. guianensis was performed at Reserva Florestal Adolpho Ducke, located km 26 of Estrada Manaus-Itacoatiara (AM-010) on Manaus, AM, with the geographical coordinates $0^{\circ} 10^{\prime} \mathrm{S}, 67^{\circ} 05^{\prime} \mathrm{W}$, on the summer period of 2010 . The botanical identification was performed by the dispatch of an exsiccate at the Herbarium of the National Institute for Amazon 
Research (INPA), where it was registered by the number 188.485 and identified by the researcher Doctor José Eduardo da Silva Ribeiro.

The barks were dried in an electric heater with air circulation at a temperature of $50^{\circ} \mathrm{C}$ during 48 hours. After, the dried barks were grinded for the increase of surface area, and subjected to three extractions by percolation with ethanol P.A. $95 \%$ at room temperature during three days, each percolation. After the evaporation of ethanol, the ethanolic extract, named MGCE, was obtained. Part of the ethanolic extract was destined for the isolation and purification of active principles, while the other part of the extract was directed to antibacterial activity assay.

The isolation and purification of the chemical constituents of the ethanolic extract of the barks were performed by glass column chromatography, using as standing phase silica gel of Merck and Vetec ( $\mu \mathrm{m}$ 63-200). The length and diameter of the columns changed according to the amounts of silica and samples used. For Thin Layer Chromatography (TLC), plates of silica gel 60 ( $\mu \mathrm{m} 2-25)$ above polyesther T - 6145, Sigma Chemical CO (with fluorescence label of $250 \mathrm{~nm}$, from Carlo Erba trademark.

The solvants used in the cromatographic elution were: n-hexane, ethyl acetate and methanol, pure or combined in an increasing gradient of polarity, from which fractions of $250 \mathrm{~mL}$ each were collected. After concentration in rotaevaporator Labor and repeated chromatographc procedures in silica gel columns, lead to the obtaining of some isolated substances. The revelation of the substances chromatographed by TLC were carried out by exposition of the analytical plaques in ultraviolet light (UV), revealed in a wavelength of $254 \mathrm{~nm}$ and pulverized with an universal revelator (mixture of ethanol: acetic acid: sulphuric acid - 80:10:10), followed by warming in a heater, between $50-100^{\circ} \mathrm{C}$, during approximately five minutes.

The mass specters were obtained by electronic impact (70 Ev) on a CG/MS Hewlett - Packard 5971 instrument using a dimethylpolysiloxane BD-1 capillary column ( $30 \mathrm{~m} \times 0,25 \mathrm{~mm})$, using He as carrier gas and temperatures of $250^{\circ} \mathrm{C}$ in the injector, $200^{\circ} \mathrm{C}$ in the detector and in the column varying $1^{\circ} / \mathrm{min}$ between $35-180^{\circ} \mathrm{C}$ and $10^{\circ} \mathrm{C} / \mathrm{min}$ in the interval of $180-250^{\circ} \mathrm{C}$.

The study of biological activity of the ethanolic extract and isolated substances of the barks of M. guianensis against S. aureus (ATCC 29213), methicillin resistant S. aureus (MRSA), K. pneumoniae (ATCC 13883), P. aerugionosa (ATCC 27853) and E. coli (ATCC 25922) were carried out at Laboratório de Microbiologia do Centro de Pesquisa em Medicina Tropical (CEPEM), on Porto Velho-RO, where the Standard Operational Procedure (SOP) was used to execute the agar diffusion test.

In the agar diffusion technique, it was observed the resistance profile and sensibility of bacteria against isolated substances of $M$. guianensis by growth inhibition halos in vitro as recommended by Clinical and Laboratory Standards Institute (CLSI), with modifications suggested by Cursino et al. (2013) and Pieri et al. (2010).

$10 \mathrm{~mL}$ of LB agar were spilled on $90 \times 15$ Petri dishes, which was named inferior layer. After solidification of this layer, $15 \mathrm{~mL}$ of Müller-Hinton agar were put into the inferior layer, being named superior layer. After culture solidification, cylindrical holes were made by using sterile tips of $200 \mu \mathrm{L}$, where there must be equidistance between the holes to avoid convergent inhibition zones.

On the surface of Müller-Hinton agar culture medium, the seeding was done by an impregnated swab with the inoculus previously adjusted at 0,5 on McFarland scale of the bacteria $S$. aureus (ATCC 29213), methicillin resistant S. aureus (MRSA), K. pneumoniae (ATCC 13883), P. aeruginosa (ATCC 27853) and E. coli (ATCC 25922).

At the holes were added $40 \mu \mathrm{L}$ of positive control at the concentration of $0,6 \mathrm{mg} / \mathrm{mL}$ and the isolated substances with the concentrations of $40,20,10$ and $5 \mu \mathrm{g} / \mathrm{mL}$. After the administration of the isolated substances, the plaques (dishes) were incubated at $37^{\circ} \mathrm{C}$ temperature during 24 hours. With the diffusion of the product in agar, sensitive bacteria to the substances presented an inhibition halo around the hole. 
The reading of halos was measured in millimeters using a millimetric ruler. The diameters of total inhibition halos (judged by naked eye) were measured, including the hole diameter. The inhibition halo was considered to be the area without visually detectable growth.

The criterion for assessing inhibitory products was the presence of inhibition halos around the holes. The sensibility profile of target-bacteria to tested products was classified according to the following scale: resistant (absence of inhibition halo), little sensitive (up to $10 \mathrm{~mm}$ diameter halos); moderately sensitive (between 20 and $30 \mathrm{~mm}$ halos) and severely sensitive (over $30 \mathrm{~mm}$ halos).

The inhibition zones obtained for the positive control were used for comparison of bacterial sensitivity profile. The tests were performed in duplicates, and the positive results were confirmed with one more repetition, in duplicates, and the final result was determined by the arithmetic mean of the diameters of inhibition halos by the software GraphPad Prism 5.0.

\section{Results and discussion}

Repeated chromatographic procedures of MGCE lead to the isolation of four substances named MGFEAC-1, MGFEAC-2, MGFEAC-3 and MGFEAC-4, which after analyses of spectroscopic data of ${ }^{1} \mathrm{H}$ and uni and bidimensional ${ }^{13} \mathrm{C}$, IV and EM RMN, lead to the conclusion that MGFEAC-1 and MGFEAC-4 were actually mixtures of triterpenes, where MGFEAC-1 corresponds to the triterpenes friedeline and friedelol, and MGFEAC-4 corresponded to tingenine $\mathrm{B}$ and tingenone. MGFEAC-2 and MGFEAC-3 were identified as the triterpenes 29-hidroxyfriedelan-3-one and 16hidroxyfriedelan-3-one, respectively. These compounds were isolated from the bark of this plant (FACUNDO et al., 2015).

Phytchemical studies carried out in plants of the genus Maytenus revealed the triterpenes friedeline and friedelol can be considered chemosystematic markers of the genus (NOSSACK et al., 2000).

Triterpenes present significant interest due to its various biological activities, serving as candidates or prototypes of new medicines (ALVARENGA \& FERRO, 2006). Studies with friedeline showed antiproliferative, proapoptotic (MARTUCCIELLO et al., 2010), anti-inflammatory, analgesic and antipyretic, (ANTONISAMY et al., 2011) and allelopathic activities (SANTOS et al., 2008).

According to studies carried out by Huyke et al. (2006), the pentacyclic triterpenes are responsible for the activity in the treatment of actinic keratosis, a skin wound caused by sun that is characterized by reddish or slightly brownish areas with rough surfaces, indicating the pentacyclic triterpenes are the main cause of the activity.

Quinonamethide triterpenes are compounds of isolation restricted to plants belonging to the Celastraceae family (CURSINO et al., 2000). Tingenone is a quinonamethide triterpene isolated from various plants of this family, among them M. acanthophylla (OLIVEIRA et al., 2006). Recent works carried out by Silva et al. (2013), indicate tingenone has potent activity against Microcystis novacekii, a cyanobacteria able of forming florations and producing toxins, named microcystins, which are involved in environmental accidents, and are largely responsible for cases of both human and animal intoxication.

The evaluation of substances contamination previously performed to the antimicrobial test indicated these substances were free of contamination by bacteria and fungi, without development of other colonies on both LB and agar media after incubation. These results revealed the substances presented good microbiological conditions in the present work.

According to the results obtained by SOP, the four isolated substances MGFEAC-1, MGFEAC2, MGFEAC-3 and MGFEAC-4 presented biological activity for S. aureus (Table 1), MRSA (Table 2), $P$. aeruginosa (Table 3) and K. pneumoniae (Table 4), with growth inhibition halos on the tested concentrations being observed.

In table 1 it is noted the concentration of $20 \mu \mathrm{g} / \mathrm{mL}$ obtained the best results when compared to the positive control (cloranfenicol), exhibiting inhibition halos ranging from 12 to $18 \mathrm{~mm}$ for the tested bacteria. 
The triterpene 29-hidroxyfriedelan-3-one (MGFEAC-3), was also isolated from the roots of Salacia kraussi Miers and is cited in literature because of its potent cytotoxicity against HT-29 cell line (human colon adenocarcinoma) and because of its antimalarial activity (FIGUEIREDO et al., 1998).

Table 1: Biological activity of isolated compounds of M. guianensis in different concentrations against S. aureus in $\mathrm{mm}^{*}$

\begin{tabular}{lllll}
\hline Samples & \multicolumn{4}{c}{ Concentration $(\mu \mathrm{g} / \mathrm{mL})$} \\
\cline { 2 - 5 } & 40 & 20 & 10 & 5 \\
\cline { 2 - 4 } & 18 & 12 & 16 & 18 \\
MGFEAC-2 & 12 & 12 & 13 & 14 \\
MGFEAC-3 & 24 & 14 & 24 & 24 \\
MGFEAC-4 & 18 & 18 & 18 & 18 \\
P. CONTROL & 30 & 30 & 30 & 30 \\
\hline
\end{tabular}

* Results accompanied by mean and standard deviation

Furthermore, this compound presented antimicrobial activities against S. aureus, Bacillus cereus and Candida albicans in the concentration of $5 \mu \mathrm{g} / \mathrm{mL}$, inhibiting between $8-10 \mathrm{~mm}$ relative to positive control (cloranfenicol) (OLIVEIRA, 2014).

In table 2 it can be noted the concentrations of 10 and $40 \mu \mathrm{g} / \mathrm{mL}$ had the best results relative to positive control (cloranfenicol), showing inhibition halos from 9 to $12 \mathrm{~mm}$ for the tested bacteria. The triterpene 29-hidroxyfriedelan-3-one (MGFEAC-3) presented the best activity profile in comparison to the other tested substances regardless of concentrations used.

Table 2: Biological activity of isolated compounds of $M$. guianensis in different concentrations against P. MRSA in $\mathrm{mm}^{*}$

\begin{tabular}{lllll}
\hline Samples & \multicolumn{4}{c}{ Concentration $(\mu \mathrm{g} / \mathrm{mL})$} \\
\cline { 2 - 5 } & 40 & 20 & 10 & 5 \\
\cline { 2 - 4 } & 11 & 12 & 10 & 13 \\
MGFEAC-2 & 9 & 10 & 10 & 16 \\
MGFEAC-3 & 12 & 12 & 12 & 12 \\
MGFEAC-4 & 12 & 12 & 12 & 12 \\
P. CONTROL & 30 & 30 & 30 & 30 \\
\hline
\end{tabular}

* Results accompanied by mean and standard deviation 
In table 3 , it can be noted the concentration of $10 \mu \mathrm{g} / \mathrm{mL}$ had the best results when compared to positive control (cloranfenicol), showing inhibition halos from 12 to $13 \mathrm{~mm}$ for tested bacteria and according with the specific SOP the sensitivity profile was moderately sensitive.

Table 3: Biological activity of isolated compounds of $M$. guianensis in different concentrations against $P$. aeruginosa in $\mathrm{mm}^{*}$

\begin{tabular}{lllll}
\hline Samples & \multicolumn{4}{c}{ Concentration $(\mu \mathrm{g} / \mathrm{mL})$} \\
\cline { 2 - 5 } & 40 & 20 & 10 & 5 \\
\cline { 2 - 5 } MGEAC-1 & 12 & 12 & 12 & 14 \\
MGFEAC-2 & 12 & 12 & 12 & 12 \\
MGFEAC-3 & 18 & 18 & 12 & 18 \\
MGFEAC-4 & 12 & 12 & 13 & 16 \\
P. CONTROL & 30 & 30 & 30 & 30 \\
\hline
\end{tabular}

${ }^{*}$ Results accompanied by mean and standard deviation

The triterpene 29-hidroxyfriedelan-3-one was isolated one more time from the barks of $M$. guianensis, and the fact that it presented a better profile relative to the rest of the substances tested, as well as for S. aureus and MRSA, is highlighted again. In table 4 it can be noted the concentrations of 10 and $20 \mu \mathrm{g} / \mathrm{mL}$ had the best results when compared to positive control (cloranfenicol) showing inhibition halos of roughly $12 \mathrm{~mm}$ for the tested bacteria and according to the specific SOP was little sensitive.

Table 4: Biological activity of isolated compounds of $M$. guianensis in different concentrations against K. pneumoniae in $\mathrm{mm}^{*}$

\begin{tabular}{lllll}
\hline Samples & \multicolumn{4}{c}{ Concentration $(\mu \mathrm{g} / \mathrm{mL})$} \\
\cline { 2 - 5 } & 40 & 20 & 10 & 5 \\
\cline { 2 - 5 } MGFAC-1 & 14 & 12 & 12 & 17 \\
MGFEAC-2 & 12 & 12 & 12 & 13 \\
MGFEAC-3 & 12 & 12 & 12 & 12 \\
MGFEAC-4 & 9 & 12 & 12 & 12 \\
P. CONTROL & 30 & 30 & 30 & 30 \\
\hline
\end{tabular}

${ }^{*}$ Results accompanied by mean and standard deviation

The triterpene tingenone, one of the components presents in MGFEC-4, has antibacterial activity against $S$. petenensis (SETZER et al., 2001) and the mixture MGFEC-4 has antioxidant activity (HURTADO, 2013). The triterpenes tingenone and tingenine $B$, separated from each other, presented inhibitory effect on the enzyme aldose reductase, suggesting an antidiabetic potential (Morikawa et al., 2003).

A possible positive response of the tested substances over the bacteria was the utilization of DMSO on the concentration of 1-2 \%, being an ideal concentration for its use in experiments, demonstrating the performance in the dissolution of the samples evaluated in this biological assay, as well as facilitated the dispersion of it in the culture medium, thus improving the quality of procedures with isolated substances.

According some authors the DMSO was inert for the development of E. coli, Staphylococcus sp, Streptococcus sp and Klebsiella sp (DALMARCO et al., 2007), for aminoglycoside-resistant E. coli (COUTINHO et al., 2009) and for Mycoplasma arginini, M. hominis and Ureaplasma urealyticum 
(CORDOVA et al., 2010). Sufredini et al., (2006), using DMSO at $50 \%$ did not find toxicity for Grampositive bacteria (S. aureus e E. faecalis) and Gram-negative bacteria (E. coli e P. aeruginosa).

Porfirio et al. (2009) and Ribeiro \& Moura (2009) verified antibacterial activity in the extract of Eleutherine plicata Herb (marupazinho), showing higher activity against the gram positive bacterium $S$. aureus. The presence of quinonamethide tritepernes and tannins in the extract may be the main cause by the antimicrobial activity of the plant (DJIPA et al., 2000).

Correia et al. (2008) in his study with the crude extract of Geissospermum argenteum reported antimicrobial activity against $P$. aeruginosa strains on the concentrations of $20 \mu \mathrm{g} / \mathrm{mL}$ and $80 \mu \mathrm{g} / \mathrm{mL}$ for sensitive $S$. aureus and $5 \mu \mathrm{g} / \mathrm{mL}$ for multi-resistant $S$. aureus.

According on the antimicrobial activity by agar diffusion technique in wells of isolated compounds of M. guianensis, the results here presented against $S$. aureus, MRSA, P. aeroginosa and K. pneumoniae present one more important evidence for the conclusion that plants are natural sources of antimicrobial substances that are not only active against pathogens and pests, but also may represent a feasible alternative of overcoming microbial resistance mechanisms.

Similar results were found by Annan et al. (2009) using friedeline, also isolated in the present work, from the methanolic extract of Paullinia pinnata L. roots against S. aureus and MRSA using the MIC on the concentration of $256 \mu \mathrm{g} / \mathrm{mL}$ relative to positive control using tetracycline (MIC= 128 $\mu \mathrm{g} / \mathrm{mL}$ ). However, other authors suggest that biological assays aiming toxicity at different concentrations must be carried out.

Ogunnusi et al. (2010), after isolating friedeline and friedelanol of the ethanolic extract of leaves of Euphorbia kamerucica Pax, performed antibacterial activity assays on the growth of $P$. aeruginosa, E. coli and S. aureus on the concentrations of 100, 75 and $50 \mu \mathrm{g} / \mathrm{mL}$, respectively, by agar disk diffusion technique in wells and verified after 24 hours, growth inhibition zones ranging from 9 to $10 \mathrm{~mm}$ for $S$. aureus and from 13 to $15 \mathrm{~mm}$ for $P$. aeruginosa on the concentration of $50 \mu \mathrm{g} / \mathrm{mL}$. However, negative results were found in E. coli, where inhibition halos were not observed when compared to other tested bacteria.

Other studies reveal that with the gram-negative bacterium, E. coli, the substances and plant extracts are not efficient, that is, they do not present inhibition halos on the tested concentrations, pointing the fact these bacteria, besides cell wall, present and external membrane that acts as a barrier for many substances, including chemotherapics (NIKAIDO, 2003; YEAGLE, 2012).

This is noteworthy, since the cell walls of gram-negative bacteria are more complex than those of gram-positive, since besides having a cytoplasmic membrane and a thin layer of peptideoglycans, they also have an external membrane covering all of them. This external membrane serves as a selective barrier that regulates the passage of some substances towards inside and outside of the cell (SOARES, 2013). Similar results were found by Carvalho et al. (2014) where no antimicrobial activity at any of the concentrations for the ethanolic and ciclohexanic extracts of Matricaria chamomilla against E. coli was observed, on both agar and broth diffusion techniques.

The fact that the substances isolated did not present antimicrobial activity against $E$. coli does not means they are not active against other species of pathogenic bacteria tested, since other plant species have comproved activity against these bacteria, being noted there is variation in sensibility for each type of substance assayed, suggesting new concentrations to be tested.

It is likely that the difference of antimicrobial activity is related not only to biological activity of the substances, but also due to the presence of one of the structures of external membrane of Gramnegative bacteria, which might prevent the passage of molecules by this membrane (FRANÇA et al., 2009), besides the particularities belonging to different resistance mechanisms of lineages.

Ribeiro \& Soares (2000) stated that several factors influence the results of agar well diffusion technique, such as: presence of bacterial enzymes, medium composition, substance diffusion in the medium, inoculus density, incubation period, temperature, and stability of the substance used.

According to Estrela (2000), the method of Agar diffusion does not offer conditions for comparison between substances with distinct solubitities and diffusibilities. Analyzing substances 
with different dissociation and diffusion capabilities, it can be noted some tested substances did not present difficulties regarding diffusion and dissociation in agar, however, in solubility tests with DMSO, the turbidity of these substances was high, hampering the short-term solubility.

Although the exact mechanism by which the isolated substances are acting on the analyzed bacteria is unknown, it is known that substances with antimicrobial activity might interfere on protein synthesis, cell wall synthesis, cell wall degradation, and folic acid biosynthesis (BAX et al., 2000).

\section{Conclusion}

The results of this work, together with the data in literature, show clearly that M. guianensis is a rich source of both friedelane and quinonamethide classes triterpenes, and according to the data cited along this manuscript, the triterpenes belonging to this class have shown several biological activities, strengthening the medicinal status of this plant. Further, this work presents the first report of results that show the efficacy of the substances of M. guianensis on four tested ATCC bacteria using the agar well diffusion technique.

\section{Acknowledgements}

The authors thank the National Council for Scientific and Technological Development (CNPq) for financial support and the Research Support Foundation of Amazonas State (FAPEAM) for granting the scholarship for the first author.

\section{References}

ALMEIDA, M.T.R.; LUCI, C.R.; PADRÓN, J.M.; PALERMO, J.A. (2010). Antiproliferative terpenoids and alkaloids from the roots of Maytenus vitidaea and Maytenus spinosa. Phytochemistry, 71(14): 17411748 .

ALVARENGA, E.; FERRO, E.A. (2006). Bioactive triterpenes and related compounds from Celastraceae. Studies in Natural Studies in Natural Products Chemistry, 33(1): 239-242.

ANNAN, K.; ADU, F.; GBEDEMA, S.Y. (2009). Friedelin: a bacterial resistance modulator from Paullinia pinnata L. Journal of Science and Technology, 29(1): 152-159.

ANTONISAMY, P.; DURAIPANDIYAN, V.; IGNACIMUTHU, S. (2011). Anti-inflammatory, analgesic and antipyretic effects of friedelin isolated from Azima tetracantha Lam. in mouse and rat models. Journal of Pharmacy and Pharmacological, 63(1): 1070-1072.

BAX, R.; MULLAN, N.; VERHOEF, J. (2000). The millennium bugs - the need for and development of new antibacterials. International Journal of Antimicrobial Agents, 16(1): 51-59.

BORRÁS, M.R.L. (2003). Plantas da Amazônia: medicinais ou mágicas - Plantas comercializadas no Mercado Municipal Adolpho Lisboa. Manaus: Valer.

CARVALHO, C.A. (2007). Avaliação do potencial antifúngico, antioxidante e citotóxico dos extratos de Jacaranda decurrens cham. (carobinha). [dissertação]. Universidade de Ribeirão Preto: USP.

CARVALHO, A.F.; SILVA, D.M.; SILVA, T.R.C.; SCARCELLI, E.; MANHANI, M.R. (2014). Avaliação da atividade antibacteriana de extratos etanólico e de ciclohexano a partir das flores de camomila (Matricaria chamomilla L.). Revista Brasileira de Plantas Medicinais, 16(3): 521-526. 
CORDOVA, S.M.; BENFATTI, C.S.; MAGINA, M.D.A.; GUEDES, A.; CORDOVA, C.M. (2010). Análise da atividade antimicrobiana de extratos isolados de plantas nativas da flora brasileira frente à Mycoplasma arginini, M. hominis e Ureaplasma urealyticum. RBAC, 42(4): 241-244.

CORREIA, A.F.; SEGOVIA, J.F.O.; GONÇALVES, M.C.A.; OLIVEIRA, V.L.D.E.; SILVEIRA, D.; CARVALHO, J.C.T.; KANZAKI, L.T.B. (2008). Amazonian plant crude extract screening for activity against multidrug- resistant bacteria. European Review for Medical and Pharmacological Sciences, 12(1): 369-380.

COUTINHO, H.D.M.; COSTA, J.G.M.; LIMA, E.O.; FALCÃO, S.V.S.; SIQUEIRA-JÚNIOR J.P. (2009). In vitro interference of Hyptis martiusii Benth. \& chlorpromazine against an aminoglycoside-resistant Escherichia coli. Indian Journal Medicinal Research, 129(1): 566-568.

CURSINO, L.M.C.; SANTOS, I.; MARIÚBA, L.A.; JEFFREYS, M.F.; LIMA, N.M.; OLIVEIRA, J.L.; ORLANDI, P.P.; NUNES, C.V. (2011). Antibacterial activity of Minquartia guianensis extracts and phytochemical evaluation. Emirates Journal of Food Agriculture, 23(6): 505-510.

DALMARCO, E.M.; GUIMARÃES, C.L.; GUEDES, A.; CALDERARI, M.T. (2007). Análise da atividade antibacteriana (in vitro) de plantas da flora brasileira utilizados pela medicina popular. Revista Ciências da Saúde, 25(1): 133-142.

DING, Y.; LIANG, C.; KIM, J.H.; LEE, Y.M.; HYUN, J.H.; KANG, H.K.; KIM, J.A.; MIN, B.S.; KIM, Y.H. (2010). Triterpene compounds isolated from Acer mandshuri and their anti-inflammatory activity. Bioorganic Medicinal Chemical Lettems, 20(5): 1528-1531.

DIJPA, C.D.; DELMÉE, M.; QUETIN-LECLERC, J. (2000). Antimicrobial activity of bark extracts of Syzygium jambo (L.) Alston (Myrtaceae). Journal of Ethnopharmacology, 71(1): 307-313.

DUARTE, L.P.; FIGUEIREDO, R.C.; DE SOUZA, G.F.; SOARES, D.B.S.; RODRIGUES, S.B.V.; SILVA, F.C.; SILVA, G.D.F. (2010). Chemical constituents of Salacia elliptica (Celastraceae). Química Nova, 33(4): 900-903.

DUKE, J.A.; VÁSQUEZ, R. (1994). Amazonian ethnobotanical dictionary. Florida: CRC Press, Boca Raton.

ESTRELA, C.R. (2000). Eficácia antimicrobiana de soluções irrigadoras de canais radiculares. [dissertação]. Universidade Federal de Goiás: UFG.

FACUNDO, V.A.; MENEGUETTI, D.U.O.; MILITÃO, J.S.L.T.; LIMA, R.A.; HURTADO, F.B.; CASSEB, A.A.; TEIXEIRA, L.F.; SILVA, I.C.; SILVA, G.V.J.; JÚNIOR-LACERDA, V. (2015). Chemical constituents from Maytenus guianensis Klotzsch ex Reissek (Celastraceae) Amazon rainforest. Biochemical Systematics and Ecology, 58(1): 270-273.

FIGUEIREDO, J.N.; RAZ, B.; SEQUIN, U. (1998). Novel quinone methides from Salacia kraussii with in vitro antimalarial activity. Journal of Natural Products, 61(6): 718-723.

FONSECA, A.P.N.D.; SILVA, G.D.F.; CARVALHO, J.J.; SALAZAR, G.D.C.M.; DUARTE, L.P.; SILVA, R.P.; TAGLIATI, C.A.; ZANI, C.L.; NEVES, T.M.A.; PERES, V.; VIEIRA-FILHO. S.A. (2007). Estudo fitoquímico do decocto das folhas de Maytenus truncata Reissek e avaliação das atividades 
antinociceptiva, antiedematogênica e antiulcerogênica de extratos do decocto. Química Nova, 30(4): 842-847.

FRANÇA, H.S.; KUSTER, R.M.; RITO, P.N.; OLIVEIRA, A.P.; TEIXEIRA, L.A.; ROCHA, L. (2009). Atividade antibacteriana de floroglucinois e de extrato hexânico de Hypericum brasiliense Choysi. Química Nova, 32(1): 1103-1106.

HURTADO, FB. (2013). Contribuição ao estudo fitoquímico e biológico da entrecasca da espécie Maytenus guianensis Klotzsch ex Reissek. [tese]. Universidade Federal de Rondônia: UFRO; 2013.

HUYKE, C.; LASZCZYK, M.; SCHEFFLER, A.; ERNEST, R.; SCHEMPP, C.M. (2006). Treatment of actinic keratoses with birch bark extract: a pilot study. Journal the Deutschen Dermatologischen Gesellschaft, 4(1): 130-132.

KENNEDY, M.L.; LLANOS, G.G.; CASTANYS, S.; GAMARRO, F.; BAZZOCCHI, I.L.; JIMENEZ, I.A. (2011). Terpenoides from Maytenus species and assessment of their reversal activity against a multidrug-resistant Leishmania tropica Line. Chemical Biodiversity, 8(12): 2291-2298.

LIMA, E.S.; VARGAS, F.S.; POHLIT, A.M. (2010). Antioxidant, antiinflammatory and antiplatelet aggregating activities of Maytenus guyanensis bark extract. Latin American Journal of Pharmacy, 29(1): 1107-1012.

LORENZI, H.; MATOS, F.J.A. (2008). Plantas medicinais no Brasil: nativas e exóticas. 2.ed. Nova Odessa: Plantarum.

MACARI, P.A.T.; PORTELA, C.N.; POHLIT, A.M. (2006). Antioxidant, cytotoxic and UVB-absorbing activity of Maytenus guianesis Klotzsch (Celastraceae) bark extracts. Acta Amazônica, 36(4): 513-518.

MARTUCCIELLO, S.; BALESTRIERI, M.L.; FELICE, F.; ESTEVAM, C.S.; SANT'ANA, A.E.; PIZZA, C.; PIACENTE, S. (2010). Effects of triterpene derivatives from Maytenus rigida on VEGF-induced Kaposi's sarcoma cell proliferation. Chemical Biological Interactions, 183(1): 450-454.

MOHAMED, F.A.; PERWEZ, A. (2014). Anti-inflammatory activity and qualitative analyses of different extracts of Maytenus obscura (RICH) by high performance thin layer chromatography method. Asian Pac Journal Tropical Biomedical, 4(2): 152-157.

MORIKAWA, T.; KISHI, A.; PONGPIRIYADACHA, M.; MATSUDA, H.; YOSHIKAWA, M. (2003). Structures of New Friedelane-Type Triterpenes and Eudesmane-Type Sesquiterpene and Aldose Reductase Inhibitors from Salacia chinensis. Journal of Natural Products, 66(9): 1191-1196.

NIKAIDO, H. (2003). Molecular basis of bacterial outer membrane permeability revisited. Microbiology and molecular biology reviews, 67(4): 593-656.

NOSSACK, A.C.; VASCONCELOS, E.C.; VILEGAS, J.H.Y.; LANÇAS, F.M.; ROQUE, N.F. (2000). Quantitative analysis of triterpenes friedelin and friedelan-3-ol in Maytenus aquifolium by HRGC and HT-CGC. Phytochemical Analysis, 11(1): 243-246.

OGUNNUSI, T.A.; OSO, B.A.; DOSUMU, O.O. (2010). Isolation and antibacterial activity of triterpenes from Euphorbia kamerunica Pax., International Journal of Biological and Chemical Sciences, 4(1): 158167. 
OLIVEIRA, D.M.; SILVA, G.D.F.; DUARTE, L.P.; VIEIRA, S.A. (2006). Chemical constituents isolated from roots of Maytenus acantophylla Reissek, Celastraceae. Biochemical Systemy Ecology, 34(1): 661665.

OLIVEIRA, C.R.; SEVER, M.A.C.; DE MORAES, M.O.; DE MELO, L.V.; GOMES, A.P.; SILVA, R.L.; DOS SANTOS, M.L. (2012). Avaliação citotóxica em três linhagens de células tumorais das frações obtidas da casca do caule de Salacia crassifolia (MART). Revista Ciência Química e Farmácia, 41(2): 133-142.

OLIVEIRA, M.L.G. (2014). Avaliação in silico do potencial farmacológico e toxicológico de friedelanos, lupanos e derivados de Maytenus gonoclada Mart. [doutorado]. Universidade Federal de Minas Gerais: UFMG.

OSAKADA, A. (2009). Desenvolvimento inicial de sangue-de-dragão (Croton lechleri MULL. ARG) sob diferentes classes de solos, corretivos e níveis de luminosidade da Amazônia Central. Instituto Nacional de Pesquisas da Amazônia: INPA.

PIERI, F.A.; JOSÉ, R.M.; GALVÃO, N.N.; NERO, L.A.; MOREIRA, M.A.S. (2010). Antimicrobial activity of autoclaved and non autoclaved copaiba oil on Listeria monocytogenes. Ciência Rural, 40(8): 1797-1801.

PORFÍRIO, Z.; MELO-FILHO, G.C.; ALVINO, V.; LIMA, M.R.F.; SANT'ANA, A.E.G. (2009). Atividade antimicrobiana de extratos hidroalcoólicos de Lafoensia pacari A. St.-Hil., Lythraceae, frente a bactérias multirresistentes de origem hospitalar. Revista Brasileira de Farmacognosia, 19(3): 785-789.

REVILLA, J. (2002). Apontamentos para a cosmética Amazônica. Manaus: SEBRAE.

RIBEIRO, M.C.; SOARES, M.M.S.R. (2000). Microbiologia prática: roteiro e manual. São Paulo: Atheneu.

RIBEIRO, A.Q.; MOURA, C.S. (2009). Informações sobre plantas medicinais e fitoterápicos no contexto da farmacoterapia. São Paulo: Atheneu.

SANTOS, L.S.; SANTOS, J.C.L.; SOUZA-FILHO, A.P.S.; CORREAA, M.J.C.; VEIGA, T.A.M.; FREITAS, V.C.M.; FERREIRA, I.C.S.; GONÇALVES, N.S.; SILVA, C.E.; GUILHON, G.M.S.P. (2008). Atividade alelopática de substâncias químicas isoladas do capim-marandu e duas variações em função do $\mathrm{pH}$. Planta daninha, 26(3): 531-538.

SANTOS, V.A.F.F.M.; LEITE, K.M.; SIQUEIRA, M.C.; REGASINI, L.O.; MARTINEZ, I.; NOGUEIRA C.T.; GALUPPO, M.K.; STOLF, B.S.; PEREIRA, A.M.S.; CICARELLI, R.M.B.; FURLAN, M.; GRAMINHA, M.A.S. (2013). Antiprotozoal activity of quinonemethide triterpenes from Maytenus ilicifolia (Celastraceae). Molecules, 18(1): 1053-1062.

SETZER, W.N.; HOLLAND, M.T.; BOZEMAN, C.A.; ROZMUS, G.F.; SETZER, M.C.; MORIARITY, D.M.; REEB, S.; VOGLER, B.; BATES, R.B.; HABER, W.A. (2001). Isolation and frontier molecular orbital investigation of bioactive quinone-methide triterpenoids from the bark of Salacia petenensis. Planta Medicinal, 67(1): 65-69. 
SILVA, F.C.; GUEDES, F.A.F.; FRANCO, M.W.; BARBOSA, F.A.R.; MARRA, C.A.; DUARTE, L.P.; SILVA, G.D.F.; VIEIRA-FILHO, S.A. (2013). Algistatic effect of a quinonamethide triterpene on Microcystis novacekii. Journal of Applied Phycology, 25(1): 1720-1723.

SOARES, A.A. (2013). Avaliação da atividade antimicrobiana do peptídeo Ocellatin-K1 isolado da secreção cutânea de Leptodactyllus knudseni (Anura: Leptodactylidae). [graduação]. Universidade Federal de Rondônia: UFRO.

SOUSA, G.F.; DUARTE, L.P.; ALCANTARA, A.F.C.; SILVA, G.D.; VIEIRA-FILHO, A.S.; SILVA, R.R.; OLIVEIRA, D.M.; TAKAHASHI, J.A. (2012). New triterpenes from Maytenus robusta: structural elucidation based on NMR experimental data and theoretical calculations. Molecules, 17(11): 13491356.

SPIVEY, A.C.; WESTON, M.; WOODHEAD, S. (2002). Celastraceae sesquiterpenoids: biological activity and synthesis. Chemical Society Review, 31(1): 43-59.

SUFFREDINI, I.B.; PACIENCIA, M.L.B.; NEPOMUCENO, D.C.; YOUNES, R.N.; VARELLA, A.D. (2006). Antibacterial and cytotoxic activity of Brazilian plant extracts Clusiaceae. Memórias do Instituto Oswaldo Cruz, 101(3): 287-290.

YEAGLE, P.L. (2012). The structure of biological membranes. 3.ed. New York: CRC. 